\section{A Method of Testing the Antimalarial Properties of Compounds in vitro}

THE rate of hæmolysis produced in vitro by the hæmolytic substance isolated from normal blood plasma ${ }^{2}$ has been found to be decreased on addition of antimalarial drugs in low concentration $(1: 5,000$ to $1: 40,000)$. Closely related inactive compounds did not affect the rate of hæmolysis. Quinine, $1: 10,000$, for example, delayed the lysis rate of hæmolysis. Quinine, $1: 10,000$, for example, delayed the lysis time from one minute in the control to between 20 and 30 minutes, while a number of inactive quinoline,

pounds failed to affect the rate of lysis. Altogether, 117 substances, comprising active and inactive companying table:

\begin{tabular}{|c|c|c|c|c|}
\hline & \multirow[b]{2}{*}{$\begin{array}{c}\text { Known antinaalarial } \\
\text { activity }\end{array}$} & \multirow[b]{2}{*}{$\begin{array}{l}\text { No. of } \\
\text { drugs }\end{array}$} & \multicolumn{2}{|c|}{ Result of lysis test } \\
\hline & & & $\begin{array}{l}\text { Hæmolysis } \\
\text { delayed } \\
(=\text { active })\end{array}$ & $\begin{array}{l}\text { Hæmolysis } \\
\text { not affected }) \\
(=\text { inactive }\end{array}$ \\
\hline III & $\begin{array}{l}\text { active } \\
\text { slightly active } \\
\text { apparently inactive } \\
\text { inactive }\end{array}$ & $\begin{array}{r}39 \\
7 \\
17 \\
54\end{array}$ & $\begin{array}{r}38 \\
5 \\
5 \\
4\end{array}$ & $\begin{array}{r}1 \\
2 \\
12 \\
50\end{array}$ \\
\hline
\end{tabular}

In Group I, 38 out of 39 antimalarial compounds were found to be active by the lysis test. Groups II to IV showed a certain discrepancy between antimalarial activity and lysis test : two slightly active drugs did not inhibit the rate of lysis, while a few of the apparently inactive drugs were found to do so. These differences may be due to the following facts: (1) the conditions of the lysis test as applied in these experiments (horse erythrocytes in isotonic phosphate buffer solution, $p$ H $7 \cdot 3$ ) may as yet be far from optimal ; (2) some antimalarial drugs reveal their activity in one host only, as for example in ducks, and are inactive in chicken, canary, monkey and man. Their antimalarial action, therefore, may not have been revealed by the particular biological test used for determining their activity.

Several other hæmolytic substances such as cobra lysolecithin, saponin, sodium dodecylsulphate, sodium desoxycholate, ethylene glycol, ammonium acetate and ammonium oxalate have been subgtituted for the naturally occurring hæmolytic substance in tests with quinine, mepacrine, paludrine, and a few other active and inactive quinine, mepacrine, paludrine, and a few other active and inactive compounds. The resuits of these tests were, however, entirely inconclusive, none of the hrmolytic substances giving any useiul indication which would help to disting

inactivity of compounds. compounds and their inhibitory effect on the hæmolysis in vitro produced by the naturally occurring hæmolytic substance makes possible the introduction of an additional test for screening potential antimalarial compounds. This parallelism makes it conceivable that the malaria parasites at some stage of their development produce a metabolite closely related to the naturally occurring hæmolytic substance, and that the effect of antimalarial drugs in vivo is bound up with their action on this metabolite. The results of this work, summarized above, constitute a step towards the

the chemotherapy of malaria. My thanks are due to Prof. D. Keilin for his interest in this work and for much stimulating and critical advice; also to Dr. H. King of the National Institute for Medical Research, London, and to Dr. Imperial Chemical Industries, Ltd., who have kindly supplied me with several series of drugs.

A detailed report will appear elsewhere.

Molteno Institute,

University of Cambridge. Dec. 12.

'Iaser, H., and Friedmann, E., Nature, 156, 507 (1945).

Penetration of Water into Erythrocytes with Heavy Water as Indicator THE usual methods of studying the water metabolism of the red medium. It has not yet been possible to follow the passage of water in and out under normal isotonic conditions. This can be done now by and out under norma

Blood samples are collected from normal adults or patlents with Blood samples are collected from normal adults or patients with
pernicions anæmia; to prevent clotting, sodium citrate or heparin pernicions anæmia ; to prevent clotting, sodium citrate or heparin soded. $0 \cdot 1-0 \cdot 3$ c.c. of a $7 \cdot 9$ per cent deuterium solution in disabout 5 c.c. blood. After a time ranging from 1 minute to 45 minutes, about 5 c.c. blood. After a time ranging from 1 minute to 45 minutes, packed red cells is drawn. In one experiment the plasma was made packed red cells is drawn. In one experiment

hypotonic before the addition of heavy water. the water according to the method of Linderstrom-Iang ${ }^{2}$; density is the water according to the method of Linderstrom-I ang' ${ }^{2}$ density is given in 'units', that is, the difference, multiplied by $10^{6}$, between the density of the sample and that of pure water at the same temperature. The water of the samples is completely distilled off in vacuum, the samples being maintained at room temperature while the water is
trapped in liquid air. The water is purifled as described by Ussing and Wernsted ${ }^{2}$.

Even after a very short time, the water of the red corpuscles and that of the plasma have the same density. Water enters the ervthrocytes so quickly, both under normal conditions and in a hypotonic medium, that the existence of a continuous exchange of water between

\begin{tabular}{|c|c|c|c|c|c|}
\hline \multirow{2}{*}{$\begin{array}{l}\text { Temp. } \\
\left({ }^{\circ} \mathrm{C} .\right)\end{array}$} & \multirow{2}{*}{$\begin{array}{l}\text { Time of } \\
\text { contact }\end{array}$} & \multicolumn{2}{|c|}{ Density } & \multirow{2}{*}{$\begin{array}{l}\text { Anti- } \\
\text { clotting }\end{array}$} & \multirow{2}{*}{ Observations } \\
\hline & & Plasma & Erythrocytes & & \\
\hline $\begin{array}{l}24^{\circ} \\
24^{\circ}\end{array}$ & $\overline{6}$ & $\begin{array}{l}188 \\
136\end{array}$ & $\begin{array}{l}188 \\
136\end{array}$ & $\begin{array}{l}\text { eitrate } \\
\text { heparin }\end{array}$ & normal \\
\hline $\begin{array}{r}24^{\circ} \\
24^{\circ} \\
24^{\circ} \\
6^{\circ} \\
6^{\circ} \\
6^{\circ} \\
6^{\circ}\end{array}$ & $\begin{array}{r}4 \\
3 \\
3 \\
1 \\
21 \\
3 \\
1\end{array}$ & $\begin{array}{l}129 \\
440 \\
471 \\
153 \\
148 \\
136 \\
191\end{array}$ & $\begin{array}{l}117 \\
407 \\
528 \\
153 \\
153 \\
136 \\
181\end{array}$ & $\begin{array}{c}\text { citrate } \\
\text { ", } \\
", \\
\text { h" } \\
\text { heparin }\end{array}$ & $\begin{array}{c}\text { normal } \\
\text { ", } \\
", \\
", \\
\text { pernicious }\end{array}$ \\
\hline $\begin{array}{l}24^{\circ} \\
24^{\circ} \\
24^{\circ} \\
24^{\circ}\end{array}$ & $\begin{array}{r}3 \\
3 \\
45 \\
45\end{array}$ & $\begin{array}{l}353 \\
400 \\
295 \\
610\end{array}$ & $\begin{array}{l}353 \\
384 \\
303 \\
610\end{array}$ & $\begin{array}{c}\text { citrate } \\
\text { ", } \\
",\end{array}$ & $\begin{array}{l}\text { anæmia } \\
\text { normal } \\
\text { "' } \\
\text { blood diluted } \\
\text { with water } \\
\text { (1 vol. water } \\
+1 \text { vol. } \\
\text { blood) }\end{array}$ \\
\hline
\end{tabular}

plasma and red corpuscles must occur. Wolpers ${ }^{3}$ and Ruska ${ }^{4}$, using the electron microscope, have recently shown that the surface lave of the red corpuscles has a proteic framework, flled up by lipoid material.

Our experiments establishing the identity of the water inside and outside the erythrocyte suggest that its surface, although it shows a fulde the erythrocyte suggest that its surface, although it shows a or holes, through which water passes in and out.

\section{J. GOVABRTS.}

Laboratory of Radioactivity,

Institut de Clinique et Policlinique médicales, University of Liège.

${ }^{1}$ Linderstrom-Lang, Jacobsen, O., and Johansen, G., C.R. Lab. Carlsberg, 23, 17 (1938).

Ussing, H., and Wernstedt, A., Skand. Arch. Physiol., 88, 169 (1940). Wolpers, C., Naturwiss., 29, 416 (1941).

\section{Quantitative Assay of Aneurin (Vitamin $B_{1}$ )}

IN the course of an investigation of base-exchange of aneurin (vitamin $\mathrm{B}_{1}$ ) on zeolitic materials, it has been found that sands display properties which suggest that they possess a zeolitic surface play properties which suggest that they possess a zeolitic surface method has been developed for the estimation of vitamin $\mathrm{B}_{1}$ in wheat products.

As might be expected, it has been found that wheat ground with As might be expected, it has been found that wheat ground with sand and water gives a lower aneurin assay than wheat ground in a logical material for the subsequent recovery of basic substances is obvious.

Full details of the work done are being published. Ministry of Food,

H. N. RIDYARD.

Cereals Research Station,

St. Albans, Herts.

$$
\text { Nov. } 1 \text {. }
$$

Effect of Antiseptics on the Germination of Pollen Grains

Pollien grains from many plants can be readily germinated on 30 per cent solutions of cane sugar with 0.8 per cent of gelatine. The rate of germination varies; but in many Labiates it begins within fifteen minutes at room temperature, and growth is obvious under a $2 / 3$ objective with a micrometer eyepiece.

It has been found that many substances with bacteriostatic properties inhibit the formation of pollen tubes, in concentrations similar to bacteriostatic values. For example, phenol inhibits germination at 0.0035 per cent, and formalin at 0.01 per cent with white dead nettle pollen; and these values are similar to those found from many nettle pollen; and these values are similar to those found

Pollen grains germinate, however, in very high concentrations of penicilin. The effective concentration varies slightly from plant to penicillin. The effective concentration varies slightly from plant to plant; with white dead nettle no inhibition is found at 5,000 unt
per c.c. ; Eschscholtzia pollen is Inhibited by 250 units per c.c.

per c.c.; Eschscholtzia pollen is inhibited by 250 units per c.c. In general, then, pollen grains show the same order of sensitivity

to antiseptics as bacteria ; but their sensitivity to penicillin is negligible,
and of the same order as vertebrate cells in tissue culture. The germination of pollen grains in the Labiates does not involve cellular multiplication. Presumably the development of the pollen tube is due to endosmosis, with distension of an elastic membrane, which becomes immediately inelastic except at the tip. This view is tube ruptures at the tip; the same effect follows the lowering of tube ruptures at the

The remarkable rate at which tube development takes place makes pollen grains very suitable objects for biological test. In many species, for example, iris, there is a striking movement of granules in the tubes this movement may be studied in relation to antiseptic concentrations. How antiseptics control pollen germination is not known; one reason may be an effect on the elastic membrane of the grain; anothe an effect on the contents of the grain which determine osmosis. What ever the cause, penicillin is distinguished from other bacteriostatic agents by its inefficiency. 